ISSN 1678-3921

Journal homepage: www.embrapa.br/pab

For manuscript submission and journal contents, access: www.scielo.br/pab

\section{Physicochemical properties of Colombian cape gooseberry hybrids in the selection of high-quality materials}

\begin{abstract}
The objective of this work was to evaluate the physicochemical properties of Colombian cape gooseberry (Physalis peruviana) hybrids and to select those with the highest fruit quality based on a selection index. A total of 36 cape gooseberry hybrids obtained from crossings between nine double haploid lines from the Tibaitatá Research Center of Colombian Corporation for Agricultural Research were evaluated. The trials were conducted in a randomized complete block design, in four locations (environments), corresponding to the municipalities of Ipiales, Gualmatán, Puerres, and Pasto, in the department of Nariño, Colombia. The following variables were evaluated: cracking percentage (CP), fruit weight with calyx (FWC), juice content (JC), total titratable acidity (TTA), total soluble solids (TSS), maturity index (MI), firmness (F), ascorbic acid (AA), and respiration rate (RR). CP was affected by the environment, showing lower values in Ipiales, Gualmatán, and Puerres. The hybrid factor significantly affected all assessed variables, except RR. The selected hybrids showed higher values for TSS, MI, FWC, and AA, besides lower values for $\mathrm{CP}$ and RR. The $3 \times 9$ hybrid stands out for presenting averages that are high for AA (42.59 mg $\left.100 \mathrm{~g}^{-1}\right)$ and MI (7.91) and low for RR (49.2 $\mathrm{mg} \mathrm{CO}_{2} \mathrm{~kg}^{-1} \mathrm{~h}^{-1}$ ).
\end{abstract}

Index terms: Physalis peruviana, ascorbic acid, genetic improvement, postharvest.

\section{Propriedades físico-químicas de híbridos de physalis colombianos na seleção de materiais de alta qualidade}

Resumo - O objetivo deste trabalho foi avaliar as propriedades físico-químicas de híbridos de physalis (Physalis peruviana) colombianos e selecionar aqueles com melhor qualidade de frutos, baseado em índice de seleção. Foram avaliados 36 híbridos de physalis provenientes de cruzamentos entre nove linhagens duplo-haploides do Tibaitatá Research Center da Colombian Corporation for Agricultural Research. Os ensaios foram conduzidos em delineamento de blocos ao acaso, em quatro locais (ambientes), que corresponderam aos municípios de Ipiales, Gualmatán, Puerres e Pasto, no departamento de Nariño, na Colômbia. Foram avaliadas as seguintes variáveis: percentagem de rachaduras (PR), peso dos frutos com cálice (PFC), conteúdo de suco (CS), acidez total titulável (AA), sólidos solúveis totais (SST), índice de maturidade (IM), firmeza (F), ácido ascórbico (AA) e taxa de respiração (TR). A PR foi afetada pelo ambiente, tendo apresentado valores mais baixos em Ipiales, Gualmatán e Puerres. O fator híbrido afetou significativamente todas as variáveis avaliadas, exceto a TR. Os híbridos selecionados apresentaram 
valores mais altos para SST, IM, PFC e AA, além de valores mais baixos para PR e TR. O híbrido 3x9 destaca-se por apresentar médias elevadas de AA $\left(42,59 \mathrm{mg} 100 \mathrm{~g}^{-1}\right)$ e IM $(7,91)$ e baixa de TR $\left(49,2 \mathrm{mg} \mathrm{CO}_{2} \mathrm{~kg}^{-1} \mathrm{~h}^{-1}\right)$.

Termos para indexação: Physalis peruviana, ácido ascórbico, melhoramento genético, pós-colheita.

\section{Introduction}

Colombia is one of the main producers of cape gooseberry (Physalis peruviana L.), an exotic fruit belonging to the Solanaceae family. The fruit contains vitamins $\mathrm{A}, \mathrm{B}$, and $\mathrm{C}$, besides micronutrients, such as $\mathrm{Fe}, \mathrm{Zn}, \mathrm{P}$, and $\mathrm{Ca}$ (Lima et al., 2013), as well as bioactive compounds, including ascorbic acid, phenolic acids, and flavonoids, which result in a high antioxidant activity and health benefits (Kumar et al., 2018). Therefore, cape gooseberry can be an alternative crop to improve the economy of several countries due to its exotic flavor and nutritional properties, which have caught the interest of international markets (Fischer et al., 2014).

Despite the potential of the cape gooseberry crop, its production has decreased in recent years, mainly because the plant materials currently used exhibit a cracking problem that causes $20-45 \%$ of the harvested fruits to be discarded and also because around 15\% of the remaining fruits do not meet the quality requirements of the exporters (García-Arias et al., 2018). These issues are aggravated by the limited amount of commercially available materials. A proposed solution is to implement a crop improvement program to select superior parents suitable for hybridization, fulfilling the conditions set by the international market (Kumar et al., 2016).

However, even though some studies have been carried out using Colombian collections, research on genetic improvement is still scarce and not comprehensive (Lagos et al., 2007). In Colombia, cape gooseberry crops depend only on a cultivar known as Ecotipo Colombia (Mazorra et al., 2006; Balaguera-López et al., 2014) and on two improved varieties obtained by the Colombian Corporation for Agricultural Research (Núñez Zarantes, 2020). Therefore, the genetic improvement of the species is necessary, first by evaluating the germplasm available in the country and then by determining the genetic potential of parents and hybrids, in order to find new materials that allow overcoming the crop's agronomic and post-harvest limiting factors and that provide producers with new improved cultivars.

The objective of this work was to evaluate the physicochemical properties of Colombian cape gooseberry hybrids and to select those with highest fruit quality based on a selection index.

\section{Materials and Methods}

For the experiment, 36 cape gooseberry hybrids obtained from crossings between nine double haploid lines from the Tibaitatá Research Center of Colombian Corporation for Agricultural Research were evaluated (Table 1). The hybrids were planted in the first half of 2017, in four locations (environments) of the department of Nariño, southwestern Colombia, corresponding to the municipalities of Ipiales $\left(0^{\circ} 52^{\prime} 53.32^{\prime \prime} \mathrm{W}\right.$, $77^{\circ} 33^{\prime} 58.2^{\prime \prime} \mathrm{N}$, at $2,900 \mathrm{~m}$ altitude), Gualmatán $\left(0^{\circ} 54^{\prime} 48.21^{\prime \prime} \mathrm{W}, 77^{\circ} 34^{\prime} 05.76 " \mathrm{~N}\right.$, at $2,830 \mathrm{~m}$ altitude), Puerres $\left(0^{\circ} 54^{\prime} 20.53^{\prime \prime} \mathrm{W}, 77^{\circ} 28^{\prime} 33.52^{\prime \prime} \mathrm{N}\right.$, at $3,016 \mathrm{~m}$ altitude), and Pasto ( $01^{\circ} 11^{\prime} 48.65^{\prime \prime} \mathrm{W}, 77^{\circ} 18^{\prime} 13.17^{\prime} \mathrm{N}$, at 2,746 $\mathrm{m}$ altitude).

Each trial consisted of 36 treatments distributed in a randomized complete block design with four replicates. Each experimental plot corresponded to a groove of five plants. For the useful plot, four central plants were considered, from which the fruits were collected. The harvested fruits were taken to the Plant Physiology Laboratory of Universidad de Nariño, located in Nariño, Colombia, where the physicochemical variables were analyzed.

At maturity stages 3 to 5 according to the color table established by technical standard 4580 (Icontec, 1999), $1 \mathrm{~kg}$ of fruits were taken randomly from the useful plot. Then, the following variables were evaluated: cracking percentage, considered as the number of fruits showing this defect out of 50 randomly picked ones; fruit weight with calyx (FWC), obtained by weighing 30 healthy fruits, also randomly picked, on an electronic scale with $0.01 \mathrm{~g}$ precision; juice content per fruit, considered the mean volume of juice extracted from 15 random fruits; total titratable acidity (TTA), measured by titration with $0.1 \mathrm{~N} \mathrm{NaOH}$ and expressed as percentage of citric acid; total soluble solids (TSS), determined using a refractometer and expressed as ${ }^{\circ}$ Brix; and maturity index, considered as the relationship between TSS and TTA. The 
other obtained variables were: firmness, measured using the FT 327 manual penetrometer (Facchini srl, Alfonsine, Ravenna, Italy) with a 5-mm diameter tip, which was introduced into the surface of ten fruits without epidermis, transversely to the peduncular scar; ascorbic acid content (AA), determined by the Reflectoquant RQflex 20 reflectometer (Merck KGaA, Darmstadt, Germany), according to the manufacturer's instructions, and expressed in $\mathrm{mg} 100 \mathrm{~g}^{-1}$ juice; and respiration rate (RR), obtained with the GC-2028 $\mathrm{CO}_{2}$ analyzer (Lutron Electronic Enterprise Co., Ltd., Taipei, Taiwan), keeping approximately $100 \mathrm{~g}$ of fruit without calyx in a tightly closed glass container, into which a sensor was inserted for 10 min to carry out readings, with the results expressed in $m g \mathrm{CO}_{2} \mathrm{~kg}^{-1} \mathrm{~h}^{-1}$ (Kays, 1991).

The obtained results were subjected to the combined analysis of variance, under a mixed model, where the 36 genetic materials (hybrids) were considered as a fixed effect and the locations (environments), as a random effect. When the interaction between genetic material and location was significant, the analysis was based on the behavior of the genetic materials in each location. Conversely, when the interaction was not significant, differences due to location or genetic material were determined. To identify the differences between the genetic materials, the higher values of a particular characteristic were considered those that exceeded the general average plus once the standard error $(\mu+\sigma)$ or twice its corresponding standard error $(\mu+2 \sigma)($ De la Cruz-Lázaro et al., 2010).

Table 1. Evaluated cape gooseberry (Physalis peruviana) hybrids obtained from crossings between nine parental double haploid (DH) lines from the Tibaitatá Research Center of the Colombian Corporation for Agricultural Research.

\begin{tabular}{lccccc}
\hline Parental DH & Code & Hybrid & Hybrid & Hybrid & Hybrid \\
\hline $12 \mathrm{U} 347$ & 1 & $1 \times 2$ & $2 \times 4$ & $3 \times 8$ & $6 \times 8$ \\
$12 \mathrm{U} 350$ & 2 & $1 \times 3$ & $2 \times 6$ & $3 \times 9$ & $6 \times 9$ \\
$12 \mathrm{U} 352$ & 3 & $1 \times 4$ & $2 \times 7$ & $3 \times 10$ & $6 \times 10$ \\
$12 \mathrm{U} 357$ & 4 & $1 \times 6$ & $2 \times 8$ & $4 \times 6$ & $7 \times 8$ \\
$12 \mathrm{U} 360$ & 6 & $1 \times 7$ & $2 \times 9$ & $4 \times 7$ & $7 \times 9$ \\
$12 \mathrm{U} 368$ & 7 & $1 \times 8$ & $2 \times 10$ & $4 \times 8$ & $7 \times 10$ \\
$12 \mathrm{U} 374$ & 8 & $1 \times 9$ & $3 \times 4$ & $4 \times 9$ & $8 \times 9$ \\
$12 \mathrm{U} 377$ & 9 & $1 \times 10$ & $3 \times 6$ & $4 \times 10$ & $8 \times 10$ \\
$12 \mathrm{U} 399$ & 10 & $2 \times 3$ & $3 \times 7$ & $6 \times 7$ & $9 \times 10$ \\
\hline
\end{tabular}

Finally, for the selection of the genetic material, a selection index was constructed (Delgado P. et al., 2009; Ceballos-Aguirre et al., 2012) based on the maturity index, TSS, FWC, firmness, juice content, $\mathrm{AA}, \mathrm{CP}$, and RR variables. To determine the selection index (SI), the following weights were assigned to reflect the importance of each variable in the quality of the fruit: $\mathrm{SI}=\left(\mathrm{MI}^{*} 0.4\right)+\left(\mathrm{TSS}^{*} 0.3\right)+\left(\mathrm{FWC}^{*} 0.3\right)$ $+\left(\mathrm{F}^{*} 0.3\right)+\left(\mathrm{JC}^{*} 0.2\right)+\left(\mathrm{AA}^{*} 0.2\right)-\left(\mathrm{CP}^{*} 0.6\right)-\left(\mathrm{RR}^{*} 0.1\right)$.

The selection index was applied to the standardized averages (E) obtained for each hybrid in the four locations. The standardization of the data was performed using the following equation: $E=(X i j-\mu) / \sigma$, where $\mathrm{Xij}$ is the individual observation, $\mu$ is the general average of the hybrids per variable, and $\sigma$ is the standard deviation of the variable.

The genetic materials with a selection index greater than or equal to 1.0 were selected. All analyses were performed with the SAS, version 9.4, statistical software (SAS Institute Inc., Cary, NC, USA).

\section{Results and Discussion}

All evaluated variables, except RR, differed significantly between hybrids (Table 2). In addition, for the genetic material $x$ location interaction, significant differences were only observed for cracking percentage and RR, indicating that the response of the hybrids regarding these variables was not consistent over the four studied environments.

The 4x10 hybrid showed the lowest FWC average, while the $8 \times 10$ hybrid presented the highest one (Table 3), which was lower than that of $10.69 \mathrm{~g}$ reported by García-Arias et al. (2018) when evaluating 100 accessions of cape gooseberry derived from highly homozygous genotypes (anther-derived haploids), but higher than that of $6.47 \mathrm{~g}$ found by Herrera M. et al. (2011) while assessing 54 accessions. These differences in FWC averages may be mainly attributed to the nature of the used genetic material, with a highly contrasting expression of this character, which allows selecting from working collections with a high variability.

The juice content varied from 3.46 to $4.43 \mathrm{~mL}$. The $1 \times 8,3 \times 6,7 \times 8,8 \times 10$, and $9 \times 10$ hybrids exhibited the highest juice content, indicating they could be suitable for industrial use, especially since high levels of juice and soluble solids increase yield and reduce the use of 
additional sugar, improving industry profits (Milić et al., 2016).

The AA contents of the assessed hybrids ranged

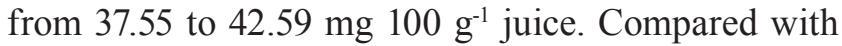
the literature, these values: exceeded those of 19.5 to

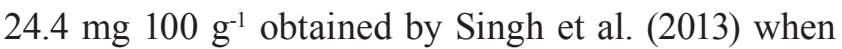
evaluating 20 cape gooseberry genotypes, were similar to those of 19.2 to $46.7 \mathrm{mg} 100 \mathrm{~g}^{-1}$ found by Herrera M. et al. (2011) for 54 cape gooseberry accessions, and were lower than those of $48.67 \mathrm{mg} 100 \mathrm{~g}^{-1}$ reported by Mendoza et al. (2012). The differences observed in the content of AA, also known as vitamin $\mathrm{C}$, can be explained by several factors such as the method used to determine it, the plant ecotype used, and the location of the crop (Olivares-Tenorio et al., 2016). The selected hybrids can be considered a good source of AA - comparable to orange (Citrus sinensis L.) and mandarin (Citrus clementina L.), with values of 46 and $41 \mathrm{mg} 100 \mathrm{~g}^{-1}$, respectively (De Ancos et al., 2017) -, which makes them a nutritional alternative to citric fruits. Moreover, those hybrids had a higher AA content than that of $32.2 \mathrm{mg} 100 \mathrm{~g} \mathrm{~g}^{-1}$ of the ecotypes currently grown in Colombia (Fischer et al., 2000).

Regarding fruit firmness, the range of the averages was from 7.66 to $8.76 \mathrm{~N}$ (Table 3), less variable than that from 3.1 to $9.9 \mathrm{~N}$ found for 100 accessions by García-Arias et al. (2018) and from 2.67 to $11.9 \mathrm{~N}$ for 54 accessions by Herrera M. et al. (2012). These differences may be linked to the state of maturity of the fruits, the genetic material used, or the location of the crop. The firmness values obtained for hybrids $1 \mathrm{x} 2$, $2 \times 7,3 \times 8,6 \times 8,7 \times 10$, and $7 \times 8$ were $8.57,8.50,8.62,8.52$,
8.61, and $8.76 \mathrm{~N}$, respectively, differing significantly from that of $83 \%$ of the evaluated materials.

According to García-Arias et al. (2018), fruit cracking and firmness are strongly inversely correlated, showing the importance of the second trait, which makes fruits less susceptible to cracking, crushing damage, and, consequently, to fungal or bacterial spoilage during postharvest operations. A greater initial firmness could lead to a longer shelf life, especially since consumers associate the softening of the product with its deterioration (Balaguera-López et al., 2015). The probability of consumer rejection rises to $50 \%$ when fruit weight loss is above $6 \%$, the standard commercial limit (Olivares-Tenorio et al., 2017).

All genetic materials evaluated had TSS higher than the minimum required, with averages ranging from $14.12{ }^{\circ}$ Brix for hybrid $3 \times 10$ to $15.16{ }^{\circ}$ Brix for $1 \times 6$ (Table 3). The 1x6, 2x3, 2x6, 2x9, 6x10, and 6x9 hybrids stood out for their significantly higher TSS averages, which ranged from 15.04-15.16 ${ }^{\circ}$ Brix and surpassed that of $83 \%$ of the assessed materials. TSS are an indirect measure of the amount of sugar in the fruit and should not be less than $14{ }^{\circ}$ Brix according to the international standard for cape gooseberry (Codex Alimentarius, 2001).

TTA ranged from 1.83 to $2.14 \%$, and the maturity index showed values from 6.88 to 7.93 . Hybrids $3 \times 10$, $3 \times 4,3 \times 9$, and $4 \times 9$ had a TTA greater than 1 standard deviation below the average of all analyzed hybrids, but lower than that of $2.1 \%$ reported by BalagueraLópez et al. (2015) for ecotype Colombia. Hybrids 2x9 and $6 \times 10$ showed a high TSS, with a maturity index from 7.66 to 7.93 , higher than that found for $81 \%$ of

Table 2. Mean squares of the combined analysis of variance of the physicochemical variables evaluated for 36 cape gooseberry (Physalis peruviana) hybrids in four locations (environments) in Colombia ${ }^{(1)}$.

\begin{tabular}{|c|c|c|c|c|c|c|c|c|c|c|}
\hline Sources of variation & DF & $\mathrm{CP}$ & FWC & $\mathrm{JC}$ & TTA & TSS & MI & $\mathrm{F}$ & $\mathrm{AA}$ & RR \\
\hline Location (L) & 3 & $179.1 *$ & $131.1 *$ & $79.2 *$ & $286.5^{*}$ & $35.1^{*}$ & $201.2 *$ & $433.4 *$ & $123.4 *$ & $1.7^{\mathrm{ns}}$ \\
\hline Replicate (L) & 12 & $0.2^{\mathrm{ns}}$ & $2.2 *$ & $2.4 *$ & $29.1 *$ & $19.9 *$ & $25.1 *$ & $139.8^{*}$ & $170.5^{*}$ & $7.3 *$ \\
\hline Genetic material (GM) & 35 & $9.4^{*}$ & $3.5^{*}$ & $2.3 *$ & $2.8 *$ & $4.5^{*}$ & $1.8^{*}$ & $3.8 *$ & $2.1 *$ & $1.5^{\mathrm{ns}}$ \\
\hline GMxL & 105 & $1.6^{*}$ & $1.0^{\mathrm{ns}}$ & $1.1^{\mathrm{ns}}$ & $1.2^{\mathrm{ns}}$ & $0.7^{\mathrm{ns}}$ & $1.1^{\mathrm{ns}}$ & $0.8^{\mathrm{ns}}$ & $1.0^{\mathrm{ns}}$ & $1.4^{*}$ \\
\hline Error & 420 & 161.1 & 0.5 & 0.3 & 0.02 & 0.3 & 0.4 & 0.4 & 14.0 & 145.4 \\
\hline $\mathrm{R}^{2}(\%)$ & & 79 & 60 & 54 & 80 & 52 & 74 & 86 & 86 & 44 \\
\hline $\mathrm{CV}(\%)$ & & 63 & 15 & 18 & 14 & 5 & 15 & 18 & 22 & 26 \\
\hline Mean & & 37.7 & 6.6 & 3.9 & 2.0 & 14.8 & 7.4 & 8.2 & 39.7 & 54.1 \\
\hline
\end{tabular}

${ }^{(1)} \mathrm{R}^{2}$, coefficient of determination; CV, coefficient of variation; DF, degrees of freedom; CP, cracking percentage; FWC, fruit weight with calyx; JC, juice content; TTA, total titratable acidity; TSS, total soluble solids; MI, maturity index; F, firmness; AA, ascorbic acid; and RR, respiration rate. *Significant

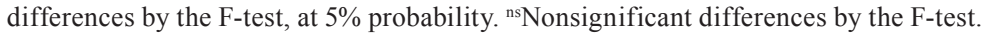


the analyzed materials. It should be noted that the best taste sensation is obtained with a high TSS/TTA ratio.

Cracking percentage was the variable with the highest coefficient of variation (Table 2), with averages from 6.50 to $88.50 \%$ (Table 4), higher than those from 0 to $59.3 \%$ reported by García-Arias et al. (2018), who attributed cracking to differences in the shape and arrangement of sub-epidermal cells or in the thickness of the cuticular membrane. The highest averages for cracking percentage were found in Pasto, where the general average was $63.28 \%$ and the lowest value was $40.33 \%$ for the $9 \times 10$ hybrid (Table 4). The lowest averages for cracking percentage were observed in Gualmatán: $6.50 \%$ for hybrid 1x2,

Table 3. Average fruit weight with calyx (FWC), juice content (JC), ascorbic acid (AA), firmness (F), total titratable acidity (TTA), total soluble solids (TSS), and maturity index (MI) of the 36 cape gooseberry (Physalis peruviana) hybrids evaluated ${ }^{(1)}$.

\begin{tabular}{|c|c|c|c|c|c|c|c|}
\hline Hybrid & FWC (g) & $\mathrm{JC}(\mathrm{mL})$ & $\mathrm{AA}\left(\mathrm{mg} 100 \mathrm{~g}^{-1}\right)$ & $\mathrm{F}(\mathrm{N})$ & TTA $(\%)$ & TSS ( ${ }^{\circ}$ Brix $)$ & MI \\
\hline $1 \times 10$ & 6.63 & 4.07 & 38.41 & 8.14 & 1.98 & 14.92 & $7.66^{*}$ \\
\hline $1 \times 2$ & 6.81 & 3.98 & 39.58 & $8.57 *$ & 2.08 & 14.87 & 7.26 \\
\hline $1 \times 3$ & 6.66 & 3.85 & 38.94 & 8.34 & 2.06 & 14.96 & 7.43 \\
\hline $1 \times 4$ & 6.56 & 3.86 & 37.55 & 7.66 & 2.04 & 14.91 & 7.49 \\
\hline $1 \times 6$ & 6.49 & 3.73 & 38.39 & 8.36 & 2.09 & $15.16^{*}$ & 7.50 \\
\hline $1 \times 7$ & 6.91 & $4.25^{*}$ & $41.35^{*}$ & 7.96 & 2.03 & 14.57 & 7.26 \\
\hline $1 \times 8$ & $7.03 *$ & $4.20 *$ & 39.61 & 8.09 & 2.02 & 14.78 & 7.49 \\
\hline $1 \times 9$ & 6.43 & 3.78 & 39.78 & 8.25 & 1.98 & 14.82 & 7.59 \\
\hline $2 \times 10$ & 6.43 & 3.81 & 37.87 & 8.38 & 2.03 & 14.74 & 7.33 \\
\hline $2 \times 3$ & 6.70 & 3.68 & 38.37 & 8.10 & $2.10^{*}$ & $15.10^{*}$ & 7.33 \\
\hline $2 \times 4$ & 6.22 & 3.56 & 39.20 & 8.26 & 2.04 & 15.01 & 7.56 \\
\hline $2 \times 6$ & 6.67 & 3.88 & 39.68 & 8.21 & 2.05 & $15.12 *$ & 7.51 \\
\hline $2 \times 7$ & 6.51 & 4.02 & 38.76 & $8.50 *$ & $2.10^{*}$ & 14.88 & 7.17 \\
\hline $2 \times 8$ & 6.42 & 3.64 & 38.42 & 8.24 & 2.05 & 14.65 & 7.31 \\
\hline $2 \times 9$ & 6.43 & 3.74 & $42.44 *$ & 7.79 & 2.03 & $15.04 *$ & $7.68 *$ \\
\hline $3 \times 10$ & 6.35 & 3.81 & 41.01 & 7.66 & 1.85 & 14.12 & $7.72 *$ \\
\hline $3 \times 4$ & 6.41 & 4.08 & $42.32 *$ & 7.76 & 1.83 & 14.27 & $7.93 *$ \\
\hline $3 \times 6$ & $7.01 *$ & $4.12 *$ & 40.01 & 8.35 & 2.03 & 14.76 & 7.46 \\
\hline $3 \times 7$ & 6.79 & 3.83 & $41.31 *$ & 8.38 & 2.01 & 14.29 & 7.31 \\
\hline $3 \times 8$ & 6.66 & 3.99 & $42.00^{*}$ & $8.62 *$ & 2.04 & 14.70 & 7.33 \\
\hline $3 \times 9$ & 6.55 & 3.90 & $42.59 *$ & 8.08 & 1.89 & 14.66 & $7.91 *$ \\
\hline $4 \times 10$ & 5.90 & 3.46 & 39.26 & 7.75 & 2.00 & 14.88 & 7.54 \\
\hline $4 \times 6$ & 6.16 & 3.47 & 39.20 & 8.22 & 2.01 & 14.68 & 7.42 \\
\hline $4 \times 7$ & 6.18 & 3.63 & 38.28 & 8.24 & 2.05 & 14.53 & 7.21 \\
\hline $4 \times 8$ & 6.15 & 3.66 & 39.14 & 7.82 & 2.04 & 14.68 & 7.29 \\
\hline $4 \times 9$ & 6.13 & 3.63 & 38.50 & 7.69 & 1.94 & 14.86 & $7.79 *$ \\
\hline $6 \times 10$ & 6.88 & 3.82 & 39.60 & 8.36 & 2.01 & $15.10^{*}$ & $7.71 *$ \\
\hline $6 \times 7$ & 6.54 & 3.68 & 39.00 & 8.32 & $2.13^{*}$ & 14.68 & 7.02 \\
\hline $6 \times 8$ & 6.65 & 3.94 & 38.24 & $8.52 *$ & 2.04 & 14.88 & 7.39 \\
\hline $6 \times 9$ & 6.52 & 3.72 & 40.86 & 8.14 & 2.06 & $15.07 *$ & 7.41 \\
\hline $7 \times 10$ & 6.59 & 3.87 & 40.34 & $8.61 *$ & $2.14^{*}$ & 14.68 & 6.93 \\
\hline $7 x 8$ & $6.94 *$ & $4.10^{*}$ & 37.73 & $8.76^{*}$ & $2.11 *$ & 14.33 & 6.88 \\
\hline $7 \times 9$ & 6.64 & 3.66 & 39.89 & 8.42 & $2.11 *$ & 14.98 & 7.30 \\
\hline $8 \times 10$ & $7.55^{*}$ & $4.43^{*}$ & 39.87 & 8.21 & 2.03 & 14.71 & 7.34 \\
\hline $8 \times 9$ & 6.87 & 4.03 & 40.64 & 8.15 & 2.07 & 14.87 & 7.29 \\
\hline $9 \times 10$ & $7.18^{*}$ & $4.19^{*}$ & 40.77 & 8.06 & 2.07 & 14.93 & 7.35 \\
\hline GA & 6.60 & 3.86 & 39.69 & 8.19 & 2.03 & 14.78 & 7.42 \\
\hline SD & 0.33 & 0.23 & 1.38 & 0.29 & 0.07 & 0.25 & 0.24 \\
\hline $\mathrm{GA}+\mathrm{SD}$ & 6.93 & 4.09 & 41.07 & 8.48 & 2.10 & 15.03 & 7.66 \\
\hline
\end{tabular}

${ }^{(1)} \mathrm{GA}$, general average of the 36 hybrids per location; and SD, standard deviation of the 36 hybrids. *More than GA + SD. 
$6.50 \%$ for $1 \times 3,8.50 \%$ for $2 \times 4$, and $9.00 \%$ for $2 \times 9$, corresponding to $11 \%$ of the genetic materials; these values were statistically lower than those obtained for the remaining materials in this location. The $7 \times 9$ and 6x7 hybrids showed cracking percentage values higher than $49 \%$, which represents greater losses, and, therefore, lower commercial yields. Although fruit cracking has been associated with water variations and nutritional problems regarding $\mathrm{Ca}, \mathrm{B}$, and $\mathrm{Cu}$ (Herrera M. et al., 2012; Criollo et al., 2014), these findings show that the effect of the genetic materials and the genetic material $\mathrm{x}$ location interaction are issues that must be further studied and clarified. The obtained results are indicative that genotypes with low fruit cracking percentages can be selected under the conditions of the municipalities of Ipiales, Gualmatán, and Puerres.

Table 4. Average cracking percentage (CP) and respiration rate (RR) of the 36 cape gooseberry hybrids (Physalis peruviana) evaluated in four locations - Gualmatán (GU), Puerres (PU), Pasto (PA), and Ipiales (IP) - in Colombia ${ }^{(1)}$.

\begin{tabular}{|c|c|c|c|c|c|c|c|c|}
\hline \multirow[t]{2}{*}{ Hybrid } & \multicolumn{4}{|c|}{$\mathrm{CP}(\%)$} & \multicolumn{4}{|c|}{$\mathrm{RR}\left(\mathrm{mg} \mathrm{CO} \mathrm{Cg}^{-1} \mathrm{~h}^{-1}\right)$} \\
\hline & $\mathrm{GU}$ & $\mathrm{PU}$ & PA & IP & $\mathrm{GU}$ & $\mathrm{PU}$ & PA & IP \\
\hline $1 \times 2$ & $6.50 *$ & $20.00 *$ & 65.50 & 19.50 & $41.70 *$ & 65.78 & 67.92 & 47.63 \\
\hline $1 \times 3$ & $6.50 *$ & 42.00 & $52.00 *$ & 14.50 & 62.60 & 59.05 & 67.88 & 58.33 \\
\hline $1 \times 4$ & 15.50 & 24.00 & 58.50 & $9.00 *$ & 61.17 & 51.11 & 57.02 & 53.59 \\
\hline $1 \times 6$ & 26.50 & 29.50 & 64.00 & 21.00 & 51.84 & $62.26^{*}$ & 50.81 & 51.83 \\
\hline $1 \times 7$ & 17.50 & 68.50 & 65.50 & 51.50 & 60.72 & 52.57 & 53.54 & 61.57 \\
\hline $1 \times 8$ & 16.00 & 34.50 & 62.50 & 22.00 & 49.47 & 61.42 & 58.25 & 53.96 \\
\hline $1 \times 9$ & 15.50 & 48.50 & $51.53 *$ & 19.00 & 52.78 & 62.21 & 50.18 & $45.17 *$ \\
\hline $1 \times 10$ & 18.00 & 23.00 & 62.00 & 11.50 & 53.92 & $42.27 *$ & 69.20 & 56.63 \\
\hline $2 \times 3$ & 10.00 & 38.00 & $53.50 *$ & 20.00 & 54.61 & $44.05 *$ & 53.12 & 50.99 \\
\hline $2 \times 4$ & $8.50 *$ & $19.00 *$ & 62.00 & 14.00 & 46.48 & 64.95 & 62.11 & 51.90 \\
\hline $2 \times 6$ & 18.00 & 36.00 & $51.50 *$ & 14.50 & 56.38 & $38.46^{*}$ & 54.88 & 51.76 \\
\hline $2 \times 7$ & 24.50 & 67.00 & 74.00 & 52.00 & 49.57 & 57.35 & 57.94 & $45.59 *$ \\
\hline $2 \times 8$ & 18.00 & 34.00 & 62.50 & 18.00 & 56.08 & 59.28 & $48.28 *$ & 53.76 \\
\hline $2 \times 9$ & $9.00 *$ & 36.00 & 64.00 & 18.50 & $45.60 *$ & $39.48 *$ & $48.46^{*}$ & 52.55 \\
\hline $2 \times 10$ & 13.50 & $18.50 *$ & 63.50 & 17.50 & 51.91 & 52.58 & 59.13 & 64.43 \\
\hline $3 \times 4$ & 23.00 & $17.50 *$ & $53.50 *$ & 13.00 & $40.77 *$ & 56.88 & 51.47 & 53.39 \\
\hline $3 \times 6$ & 30.50 & 33.00 & 62.00 & 29.50 & 59.80 & 70.30 & 59.81 & 56.98 \\
\hline $3 \times 7$ & 49.00 & 45.00 & 80.50 & 45.50 & 56.96 & $42.10^{*}$ & 52.29 & $44.68 *$ \\
\hline $3 \times 8$ & 19.50 & 37.00 & 59.00 & 36.00 & 46.35 & 48.12 & $45.06^{*}$ & $46.29 *$ \\
\hline $3 \times 9$ & 16.50 & 25.00 & $47.00 *$ & 25.00 & $40.18^{*}$ & $44.14^{*}$ & 63.68 & 48.79 \\
\hline $3 \times 10$ & 15.00 & 43.00 & 64.00 & 21.00 & 51.28 & 48.98 & 52.25 & $45.83^{*}$ \\
\hline $4 \times 6$ & 17.00 & 27.00 & 64.00 & 21.00 & 56.47 & $44.47 *$ & 50.76 & 49.94 \\
\hline $4 \times 7$ & 34.00 & 47.50 & 74.50 & 38.00 & 63.68 & 57.51 & 58.22 & $46.65^{*}$ \\
\hline $4 \times 8$ & 17.00 & 32.00 & 64.50 & 12.50 & 48.06 & 52.33 & 52.40 & 48.03 \\
\hline $4 \times 9$ & 9.50 & 22.00 & 62.00 & $6.00 *$ & 67.98 & 47.68 & 54.78 & 49.45 \\
\hline $4 \times 10$ & 13.00 & $20.50 *$ & 61.50 & 11.00 & 73.54 & 69.05 & 57.81 & 62.98 \\
\hline $6 \times 7$ & 52.50 & 71.00 & 88.50 & 75.50 & 53.40 & 52.26 & 53.97 & 58.82 \\
\hline $6 \times 8$ & 50.50 & 61.50 & 63.00 & 46.50 & 58.15 & 63.30 & $46.80^{*}$ & $38.51 *$ \\
\hline $6 \times 9$ & 33.00 & 39.50 & 69.00 & 30.00 & 52.51 & 53.29 & 68.44 & 61.19 \\
\hline $6 \times 10$ & 20.00 & 29.50 & 63.00 & 33.50 & 49.53 & 58.94 & 74.27 & 50.29 \\
\hline $7 \times 8$ & 60.00 & 68.50 & 68.00 & 54.50 & 64.09 & 45.48 & 53.30 & 55.07 \\
\hline $7 \times 9$ & 49.50 & 67.50 & 85.00 & 52.50 & 57.27 & 50.52 & 70.22 & 52.57 \\
\hline $7 \times 10$ & 30.00 & 57.50 & 70.00 & 33.00 & 52.30 & 51.81 & $44.79 *$ & 57.17 \\
\hline $8 \times 9$ & 23.00 & 26.00 & 66.00 & 34.50 & $37.54 *$ & 48.84 & 49.70 & 60.79 \\
\hline $8 \times 10$ & 27.50 & 21.50 & 60.13 & 21.50 & 57.65 & 53.01 & 51.07 & 53.77 \\
\hline $9 \times 10$ & 16.50 & $20.50 *$ & $40.33 *$ & 11.50 & 47.45 & 59.54 & 55.07 & 56.81 \\
\hline GA & 23.06 & 37.53 & 63.28 & 27.06 & 53.60 & 53.65 & 56.25 & 52.71 \\
\hline $\mathrm{SD}$ & 13.87 & 16.56 & 9.58 & 16.06 & 7.88 & 8.31 & 7.51 & 5.86 \\
\hline GA - SD & 9.18 & 20.96 & 53.69 & 11.00 & 45.72 & 45.34 & 48.74 & 46.86 \\
\hline
\end{tabular}

${ }^{(1)} \mathrm{GA}$, general average of the 36 hybrids per location; and SD, standard deviation of the 36 hybrids per location. *Less than GA - SD. 
This is important since skin cracking is a serious cape gooseberry defect considered unacceptable for the fresh fruit market (Herrera M. et al., 2011).

The RR for the total population ranged from 37.54 mg CO $\mathrm{kg}^{-1} \mathrm{~h}^{-1}$ for hybrid 8x9 in Gualmatán to 74.27 mg CO $\mathrm{kg}^{-1} \mathrm{~h}^{-1}$ for $6 \times 10$ in Pasto (Table 4). Similar values from 40 to $86 \mathrm{mg} \mathrm{CO} \mathrm{kg}^{-1} \mathrm{~h}^{-1}$ were obtained for cape gooseberry fruits at zero day of storage (Balaguera-López et al., 2015; López Enríquez et al., 2016). Previous authors concluded that cape gooseberry has a climacteric behavior since, after physiological maturity, there was an increase in RR (Lima et al., 2013; Fischer et al., 2014; López Enríquez et al., 2016).

Hybrids 8x9 in Gualmatán and 6x8 in Ipiales showed the lowest RR values of 37.54 and $38.51 \mathrm{mg} \mathrm{CO}_{2} \mathrm{~kg}^{-1}$ $\mathrm{h}^{-1}$, respectively, which were significantly lower than those of the other materials in each location. A reduced RR preserves fruit quality and delays senescence because it also lowers fruit metabolic and enzymatic activities (Silva et al., 2013). Therefore, the genetic materials with a lower respiratory activity have a longer shelf life. In the study of Balaguera-López et al. (2015), the shelf life of cape gooseberry fruits was longer under storage at $2^{\circ} \mathrm{C}$ and treatment with 1-methylcyclopropene, conditions that reduce RR.

Firmness is also inversely associated with the maturity index. Therefore, the genetic materials with a high maturity index will be more susceptible, during postharvest, to the mechanical damage caused by the enzymatic softening of the fruit epidermis, as maturation progresses (Puente et al., 2011; Africano et al., 2015). According to Herrera M. et al. (2012), when this relationship is not observed in the genetic materials, the metabolic processes associated with maturation are probably behaving differently.

AA content showed a negative, moderate, and significant correlation of -0.61 with firmness, which could be attributed to the increase in vitamin $\mathrm{C}$ in the late stages of maturation, when firmness is lower (Valdenegro et al., 2012).

The hybrids selected with a selection index higher than 1.0 correspond to $14 \%$ of the studied population (Table 5). The average maturity index of the selected materials was high, of 0.15 and 0.17 , respectively, compared with the general average and with the materials that were not selected at stage 4 of maturity according to Colombian standards (Icontec, 1999). The $3 \times 9$ and $6 \times 10$ hybrids stood out for presenting the highest maturity index average within the selected fraction. The selected hybrids had a TSS content of 0.12 and $0.14{ }^{\circ}$ Brix, both higher in comparison with the general average and the fraction that was not selected, respectively. The $6 \times 10$ and $2 \times 6$ hybrids had the highest soluble solids contents of 15.10 and 15.12 ${ }^{\circ}$ Brix, respectively, corresponding to one third of the materials with a TSS significantly higher than that of the rest of the population. The obtained values are similar to the averages of $15.5^{\circ}$ Brix reported for cape

Table 5. Average maturity index, total soluble solids (TSS), fruit weight with calyx (FWC), juice content, firmness, ascorbic acid, cracking percentage (CP), and respiration rate (RR) of the fraction selected from 36 cape gooseberry (Physalis peruviana) hybrids evaluated in four locations (environments) in Colombia ${ }^{(1)}$.

\begin{tabular}{|c|c|c|c|c|c|c|c|c|c|}
\hline Hybrid & $\begin{array}{l}\text { Maturity } \\
\text { index }\end{array}$ & $\begin{array}{c}\text { TSS } \\
\left({ }^{\circ} \text { Brix }\right)\end{array}$ & $\begin{array}{l}\text { FWC } \\
(\mathrm{g})\end{array}$ & $\begin{array}{c}\text { Juice content } \\
(\mathrm{mL})\end{array}$ & $\begin{array}{c}\text { Firmness } \\
(\mathrm{N})\end{array}$ & 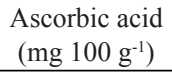 & $\begin{array}{l}\mathrm{CP} \\
(\%)\end{array}$ & $\begin{array}{c}\mathrm{RR} \\
\left(\mathrm{mg} \mathrm{CO} \mathrm{kg}^{-1} \mathrm{~h}^{-1}\right)\end{array}$ & SI \\
\hline $9 \times 10$ & 7.35 & 14.93 & $7.18^{*}$ & $4.19 *$ & 8.06 & 40.77 & $22.21 *$ & 54.72 & 1.6 \\
\hline $3 \times 9$ & $7.91 *$ & 14.66 & 6.55 & 3.90 & 8.08 & $42.59 *$ & 28.38 & $49.20 *$ & 1.5 \\
\hline $8 \times 10$ & 7.34 & 14.71 & $7.55^{*}$ & $4.43^{*}$ & 8.21 & 39.87 & 32.66 & 53.87 & 1.5 \\
\hline $6 \times 10$ & $7.71 *$ & $15.10^{*}$ & 6.88 & 3.82 & 8.36 & 39.60 & 36.50 & 58.26 & 1.2 \\
\hline $2 \times 6$ & 7.51 & $15.12 *$ & 6.67 & 3.88 & 8.21 & 39.68 & 30.00 & 50.37 & 1.1 \\
\hline MSF & 7.57 & 14.91 & 6.97 & 4.04 & 8.18 & 40.50 & 29.95 & 53.28 & \\
\hline MNS & 7.40 & 14.76 & 6.54 & 3.83 & 8.19 & 39.56 & 38.98 & 54.18 & \\
\hline GA & 7.42 & 14.78 & 6.60 & 3.86 & 8.19 & 39.69 & 37.73 & 54.05 & \\
\hline $\mathrm{SD}$ & 0.24 & 0.25 & 0.33 & 0.23 & 0.29 & 1.38 & 12.44 & 4.29 & \\
\hline DNS & 0.17 & 0.14 & 0.43 & 0.21 & -0.01 & 0.94 & -9.00 & -0.89 & \\
\hline DG & 0.15 & 0.12 & 0.37 & 0.18 & -0.01 & 0.81 & -7.78 & -0.77 & \\
\hline
\end{tabular}

(1) MSF, mean of the selected fraction; MNS, mean of the fraction not selected; GA, general average of the population; SD, standard deviation of the population; DNS, difference in relation to the materials not selected (MSF - MNS); DG, difference in relation to the genetic materials (MSF - GA); and SI, selection index. *Significant differences by the F-test, at 5\% probability. 
gooseberry genotypes when used as parents (Cely et al., 2015), but exceed those found for the Colombia ecotype, characterized as having a high sugar content of 13.4 to $14.8{ }^{\circ}$ Brix at maturity stages 4 and 5 (Valdenegro et al., 2012; Pinzón et al., 2015; OlivaresTenorio et al., 2017).

The FWC values of the selected materials were 0.43 $\mathrm{g}$, higher than that of the fraction not selected, and of $0.37 \mathrm{~g}$, higher than the general average. The average FWC values found for hybrids 9x10 and 8x10 were significantly higher than that of the total population (Table 5). These hybrids had a fruit weight similar to that of $7.22 \mathrm{~g}$ obtained for the Silvania ecotype, which could maintain a greater fruit weight compared with other commercial materials such as Kenya and Nariño Regional (Criollo et al., 2014).

The 3x9 hybrid exhibited the highest AA content among the selected materials and the total population, with an average higher than that of $32 \mathrm{mg} 100 \mathrm{~g}^{-1}$ reported by other authors for the Colombia ecotype at stage 5 of maturity (Valdenegro et al., 2012). The average AA content of the selected materials was 0.81 mg $100 \mathrm{~g}^{-1}$, higher than the general average, and 0.94 mg $100 \mathrm{~g}^{-1}$, higher than the mean of the fraction that was not selected.

In the selected fraction, the average cracking percentage was $29.95 \%$, higher than those found by other authors (Herrera M. et al., 2011; García-Arias et al., 2018). However, considering that this is a variable affected by the environment, the lowest cracking percentages were obtained in Ipiales, Gualmatán, and Puerres. The 9x10 hybrid had an average cracking percentage lower than that of the other materials. The five selected hybrids showed a difference in relation to the genetic materials (DG) of -7.78 and a difference in relation to the materials that were not selected (DNS) of -9.0 (Table 5). This indicates that the selected hybrids had a lower cracking percentage and, consequently, lower resulting losses.

The $3 \times 9$ material showed the lowest average of 49.2 mg CO $\mathrm{Kg}^{-1} \mathrm{~h}^{-1}$ for RR, lower than that of $109.1 \mathrm{mg}$ $\mathrm{CO}_{2} \mathrm{~kg}^{-1} \mathrm{~h}^{-1}$ found by Valdenegro et al. (2012) for fruits of the Colombia ecotype at stage 5 of maturity. The DG for RR was $-0.77 \mathrm{mg} \mathrm{CO} \mathrm{kg}^{-1} \mathrm{~h}^{-1}$, indicating that the selected hybrids had a lower RR in relation to that of the total population. This means that these materials could have a lower metabolic activity and extended shelf life.
Finally, the low RR observed for the $3 \times 9$ hybrid makes it a good alternative for export, as it could resist long journeys due to its low deterioration rate. In addition, its high vitamin C content of $42.59 \mathrm{mg} 100 \mathrm{~g} \mathrm{~g}^{-1}$ and high maturity index of 7.91 make it a material with good sensory and nutritional characteristics.

\section{Conclusions}

1. The response of cape gooseberry (Physalis peruviana) genotypes only varies across environments regarding the variable cracking percentage.

2. Hybrids 9x10, 3x9, 8x10, 6x10, and 2x6 present the highest selection index values.

3. The $9 \times 10,3 \times 9,8 \times 10,6 \times 10$, and $2 \times 6$ selected hybrids show better values for the soluble solids, fruit weight, ascorbic acid, maturity index, cracking percentage, and respiration rate variables.

\section{Acknowledgments}

To Gobernación de Nariño with Universidad de Nariño and to Sistema General de Regalías (SGR), for financing this research through project "Programa de Mejoramiento Genético de Uchuva (Physalis peruviana) en la Zona Alto Andina del Departamento de Nariño" (BPIN number 2013000100283).

\section{References}

AFRICANO, K.L.; ALMANZA-MERCHÁN, P.J.; BALAGUERA-LÓPEZ, H.E. Fisiología y bioquímica de la maduración del fruto de durazno [Prunus persica (L.) Batsch]. Una Revisión. Revista Colombiana de Ciencias Hortícolas, v.9, p.161-172, 2015. DOI: https://doi.org/10.17584/rcch.2015v9i1.3754.

BALAGUERA-LÓPEZ, H.E.; MARTÍNEZ C., C.A.; HERRERAARÉVALO, A. Papel del cáliz en el comportamiento postcosecha de frutos de uchuva (Physalis peruviana L.) ecotipo Colombia. Revista Colombiana de Ciencias Hortícolas, v.8, p.181-191, 2014. DOI: https://doi.org/10.17584/rcch.2014v8i2.3212.

BALAGUERA-LÓPEZ, H.E.; MARTÍNEZ, C.A.; HERRERA A., A. Refrigeration affects the postharvest behavior of 1-methylcyclopropenetreated cape gooseberry (Physalis peruviana L.) fruits with the calyx. Agronomía Colombiana, v.33, p.356-364, 2015. DOI: https://doi.org/10.15446/agron. colomb.v33n3.51896.

CEBALLOS-AGUIRRE, N.; VALLEJO-CABRERA, F.A.; ARANGO-ARANGO, N. Evaluación del contenido de antioxidantes en introducciones de tomate tipo cereza (Solanum spp.). Acta Agronómica, v.61, p.230-238, 2012. 
CELY, J.A.B.; RODRÍGUEZ, F.E.; ALMARIO, C.G.; MENESES, L.S.B. Variabilidad genética de parentales y poblaciones $\mathrm{F}_{1}$ inter e intraespecíficas de Physalis peruviana L. y P. floridana Rydb. Revista Brasileira de Fruticultura, v.37, p.179-192, 2015. DOI: https://doi.org/10.1590/0100-2945-002/14.

CODEX ALIMENTARIUS. Normas Internacionales de los Alimentos. Norma del CODEX para la uchuva (Codex Stan 226-2001). Rome: FAO, 2001.

CRIOLlO, H.; LAGOS, T.C.; FISCHER, G.; MORA, L.; ZAMUDIO, L. Comportamiento de tres genotipos de uchuva (Physalis peruviana L.) bajo diferentes sistemas de poda. Revista Colombiana de Ciencias Hortícolas, v.8, p.34-43, 2014. DOI: https://doi.org/10.17584/rcch.2014v8i1.2798.

DE ANCOS, B.; CILlA, A.; BARBERÁ, R.; SÁNCHEZMORENO, C.; PILAR CANO, M. Influence of orange cultivar and mandarin postharvest storage on polyphenols, ascorbic acid and antioxidant activity during gastrointestinal digestion. Food Chemistry, v.225, p.114-124, 2017. DOI: https://doi.org/10.1016/j. foodchem.2016.12.098.

DE LA CRUZ-LÁZARO, E.; CASTAÑÓN-NAJERA， G.; BRITO-MANZANO, N.P.; GÓMEZ-VÁZQUEZ, A.; ROBLEDOTORRES, V.; LOZANO DEL RÍO, A.J. Heterosis y aptitud combinatoria de poblaciones de maíz tropical. Phyton, v.79, p.1117, 2010.

DELGADO P., A.I.; PALACIOS C., J.H.; BETANCOURT G., C. Evaluación de 16 genotipos de quinua dulce (Chenopodium quinoa Willd.) en el municipio de Iles, Nariño (Colombia). Agronomía Colombiana, v.27, p.159-167, 2009.

FISCHER, G.; ALMANZA-MERCHÁN, P.J.; MIRANDA, D. Importancia y cultivo de la uchuva (Physalis peruviana L.). Revista Brasileira de Fruticultura, v.36, p.1-15, 2014. DOI: https://doi.org/10.1590/0100-2945-441/13.

FISCHER, G.; EBERT, G.; LÜDDERS, P. Provitamin A carotenoids, organic acids and ascorbic acid content of cape gooseberry (Physalis peruviana L.) ecotypes grown at two tropical altitudes. Acta Horticulturae, v.531, p.263-267, 2000. DOI: https://doi.org/10.17660/actahortic.2000.531.43.

GARCÍA-ARIAS， F.L.; OSORIO-GUARÍN， J.A.; NÚÑEZ ZARANTES, V.M. Association study reveals novel genes related to yield and quality of fruit in cape gooseberry (Physalis peruviana L.). Frontiers in Plant Science, v.9, art.362, 2018. DOI: https://doi.org/10.3389/fpls.2018.00362.

HERRERA M., A.M.; FISCHER, G.; CHACÓN S., M.I. Agronomical evaluation of cape gooseberries (Physalis peruviana L.) from central and north-eastern Colombia. Agronomía Colombiana, v.30, p.15-24, 2012.

HERRERA M., A.M.; ORTIZ A., J.D.; FISCHER, G.; CHACÓN S., M.I. Behavior in yield and quality of 54 cape gooseberry (Physalis peruviana L.) accessions from north-eastern Colombia. Agronomía Colombiana, v.29, p.189-196, 2011.

ICONTEC. Instituto Colombiano de Normas Técnicas y Certificación. NTC 4580: 1999: frutas frescas: u chuva: especificaciones. Bogotá, 1999.
KAYS, S.J. Metabolic processes in harvested products. IN: KAYS, S.J. Postharvest physiology of perishable plant products. New York: Van Nostrand Reinhold, 1991. p.79-136. DOI: https://doi.org/10.1007/978-1-4684-8255-3.

KUMAR, S.; BAGHEL, M.; YADAV, A.; DHAKAR, M.K. Postharvest biology and technology of berries. In: MIR, S.A.; SHAH, M.A.; MIR, M.M. (Ed.). Postharvest biology and technology of temperate fruits. Cham: Springer, 2018. p.349370. DOI: https://doi.org/10.1007/978-3-319-76843-4_15.

KUMAR, V.; SAHAY, S.; AHMAD, F.; NIRGUDE, V.; SINGH, R.S.; KHANDELWAL, A. Genetic divergence of cape gooseberry (Physalis peruviana L.) genotypes in India. International Journal of Agriculture, Environment and Biotechnology, v.9, p.1-4, 2016. DOI: https://doi.org/10.5958/2230-732x.2016.00001.2.

LAGOS, T.C; VAlLEJO, F.A.; CRIOLlO, H. Análisis de la aptitud combinatoria de algunas características del fruto de Physalis peruviana L. Agronomía Colombiana, v.25, p.36-46, 2007.

LIMA, C.S.M.; SEVERO, J.; ANDRADE, S.B. de; AFFONSO, L.B.; ROMBALDI, C.V.; RUFATO, A.D.R. Qualidade póscolheita de Physalis sob temperatura ambiente e refrigeração. Revista Ceres, v.60, p.311-317, 2013. DOI: https://doi.org/10.1590/ S0034-737X2013000300002.

LÓPEZ ENRÍQUEZ, D.F.; CUATIN RUANO, L.Y.; ANDRADE, J.C.; OSORIO MORA, O.O. Evaluación de un recubrimiento comestible a base de proteínas de lactosuero y cera de abeja sobre la calidad fisicoquímica de uchuva (Physalis peruviana L.). Acta agronómica, v.65, p.326-333, 2016. DOI: https://doi.org/10.15446/ acag.v65n4.50191.

MAZORRA, M.F.; QUINTANA, Á.P.; MIRANDA, D.; FISCHER, G.; VALENCIA, M.C. de. Aspectos anatómicos de la formación y crecimiento del fruto de uchuva Physalis peruviana (Solanaceae). Acta Biológica Colombiana, v.11, p.69-81, 2006.

MENDOZA, J.H.; ROdRIGUEZ DE S., A.; MILlÁN C., P. Caracterización físico química de la uchuva (Physalis peruviana) en la región de Silvia Cauca. Biotecnología en el Sector Agropecuario y Agroindustrial, v.10, p.188-196, 2012.

MILIĆ, D.; LUKAČ-BULATOVIĆ, M.; KALANOVIĆBULATOVIĆ, B.; MILOVANČEVIĆ, Z. Raw material requirements planning in fruit juice production. Economics of Agriculture, v.63, p.1395-1402, 2016. DOI: https://doi.org/10.5937/ekoPolj1604395M.

NÚÑEZ ZARANTES, V.M. La tecnología doble haploide en el mejoramiento genético de frutas exóticas: uchuva, Physalis peruviana L., como estudio de caso. Revista Colombiana de Biotecnología, v.22, p.3-5, 2020. DOI: https://doi.org/10.15446/ rev.colomb.biote.v22n1.88590.

OLIVARES-TENORIO, M.-L.; DEKKER, M.; VAN BOEKEL, M.A.J.S.; VERKERK, R. Evaluating the effect of storage conditions on the shelf life of cape gooseberry (Physalis peruviana L.). LWT - Food Science and Technology, v.80, p.523-530, 2017. DOI: https://doi.org/10.1016/j.lwt.2017.03.027.

OLIVARES-TENORIO, M.-L.; DEKKER, M.; VERKERK, R.; VAN BOEKEL, M.A.J.S. Health-promoting compounds in cape 
gooseberry (Physalis peruviana L.): review from a supply chain perspective. Trends in Food Science \& Technology, v.57, p.8392, 2016. DOI: https://doi.org/10.1016/j.tifs.2016.09.009.

PINZÓN, E.H.; REYES, A.J.; ÁLVAREZ-HERRERA, J.G.; LEGUIZAMO, M.F.; JOYA, J.G. Comportamiento del fruto de uchuva Physalis peruviana L., bajo diferentes temperaturas de almacenamiento. Revista de Ciencias Agrícolas, v.32, p.26-35, 2015. DOI: https://doi.org/10.22267/rcia.153202.10.

PUENTE, L.A.; PINTO-MUÑOZ, C.A.; CASTRO, E.S.; CORTÉS, M. Physalis peruviana Linnaeus, the multiple properties of a highly functional fruit: a review. Food
Research International, v.44, p.1733-1740, 2011. DOI: https://doi.org/10.1016/j.foodres.2010.09.034.

SINGH, D.B.; LAL, S.; AHMED, N.; SHARMA, O.C.; PAL, A.A.; MIRZA, A. Diversity assessment in cape gooseberry (Physalis peruviana L.) genotypes. Madras Agricultural Journal, v.100, p.273-276, 2013.

VALDENEGRO, M.; FUENTES, L.; HERRERA, R.; MOYA-LEÓN, M.A. Changes in antioxidant capacity during development and ripening of goldenberry (Physalis peruviana L.) fruit and in response to 1-methylcyclopropene treatment. Postharvest Biology and Technology, v.67, p.110-117, 2012. DOI: https://doi.org/10.1016/j.postharvbio.2011.12.021. 